DOI: 10.17951/lrp.2019.38.1.69-78

\author{
URSZULA LEWARTOWICZ \\ Uniwersytet Marii Curie-Skłodowskiej w Lublinie \\ https://orcid.org/0000-0002-0915-9486
}

\title{
KREATYWNOŚĆ JAKO PRZEDMIOT I CEL EDUKACJI KULTURALNEJ
}

\begin{abstract}
Streszczenie: Celem artykułu jest zwrócenie uwagi na doniosłość kategorii kreatywności $\mathrm{w}$ teorii i praktyce edukacji kulturalnej. Zawarte w niniejszym tekście rozważania koncentrują się wokół faktycznego oraz postulowanego miejsca kreatywności w koncepcjach edukacji kulturalnej, jej roli w praktyce szkolnej oraz celów edukacyjnych charakteryzujących tak zwaną szkołę kreatywną. W artykule przywołane zostały najważniejsze koncepcje edukacji kulturalnej uwzględniające problematykę kreatywności i twórczości oraz dokumenty strategiczne, w których wyartykułowane zostały powiązania między kreatywnością, kulturą i edukacją. Wskazano również kluczowe obszary szkolnej edukacji kulturalnej, uzasadniające potrzebę wzmocnienia i uwypuklenia idei kreatywności z perspektywy edukacji i kultury.
\end{abstract}

Słowa kluczowe: kreatywność, edukacja kulturalna, szkoła kreatywna

\section{WSTĘP}

Kreatywność stała się w ostatnim czasie kategorią na tyle nośną i modną, że zaproszono ją do wszystkich niemal obszarów i sfer życia człowieka. Przez wieki łączona była przede wszystkim ze sztuką, dziś pojawia się w salach szkoleniowych, marketingu, polityce, naukach ścisłych, jest obowiązkowym elementem w CV kandydatów na wszelkie możliwe stanowiska pracy. Nie oceniam negatywnie mody na kreatywność, stawiam jedynie nieśmiałą tezę, iż fakt jej spopularyzowania wpłynął na umniejszenie jej rangi w fundamentalnych dla kreatywności dziedzinach, jaką jest między innymi edukacja kulturalna.

Niniejszy tekst jest swoistym apelem o przywrócenie i wzmocnienie miejsca i roli problematyki kreatywności w edukacji kulturalnej. W ostatnich latach ob- 
serwujemy bowiem przesunięcie edukacyjnego myślenia o kreatywności z obszaru stricte kulturalnego w kierunku ekonomiczno-gospodarczym.

Moda na kreatywność i tendencja do jej analizowania na gruncie bardzo różnych dyscyplin naukowych w pewnym stopniu determinuje trudności natury terminologicznej. W zależności od dziedziny, w ramach której kreatywność jest definiowana, spotykamy się z jej różnymi, dość odległymi względem siebie ujęciami - od klasycznych psychologicznych koncepcji twórczości, po bardziej współczesne wizje o podłożu ekonomicznym, utożsamiające kreatywność $\mathrm{z}$ innowacyjnością. Inwestycja w wiedzę, rozwój naukowy będący źródłem innowacji, stały się podstawą wielu dokumentów koncepcyjnych i strategicznych, między innymi przyjętej w 2000 roku przez Radę Europejską Strategii Lizbońskiej (Lisbon Strategy 2000) oraz strategii Europa 2020 (Europa 2020. Strategia na rzecz inteligentnego i zrównoważonego rozwoju sprzyjającego właczeniu społecznemu). Rok 2009 został przez Parlament Europejski ogłoszony „Europejskim rokiem kreatywności i innowacji”. W uzasadnieniu podkreślono, iż „kreatywność jest nieodłączną cechą ludzką, która nie tylko manifestuje się poprzez dzieła sztuki, wzornictwo i rzemiosła, ale odnosi się również do rozwoju naukowego i technologicznego, przedsiębiorczości i społecznych innowacji. Innowacja natomiast jest realizacją nowych pomysłów wypływających z kreatywności. $Z$ tego względu zdolność do kreatywnego i innowacyjnego myślenia w równym stopniu przekłada się na zysk na polu ekonomicznym, społecznym i artystycznym" (Jagodzińska 2013, s. 330).

$\mathrm{Na}$ gruncie pedagogiki pojęcie kreatywności stosowane jest niekiedy jako synonim twórczości, częściej jednak w literaturze przedmiotu spotykamy się ze stwierdzeniem, iż kreatywność to fundament twórczości (w dodatku twórczości niższego rzędu, definiującej pewną postawę charakterystyczną dla każdej jednostki ludzkiej). W takim ujęciu kreatywność rozumiana jest jako „podstawa, zapowiedź i warunek bardziej zaawansowanej i dojrzałej twórczości” (Parys, 2013, s. 29). W związku z powyższym, mianem człowieka kreatywnego określić można $\mathrm{z}$ jednej strony wybitnego, tworzącego unikatowe dzieła sztuki bądź wynalazki twórcę, z drugiej - twórcę pomysłów unikatowych w skali niewielkich grup społecznych - rodziny, wspólnoty sąsiedzkiej czy grupy zawodowej (Szmidt 2013, s. 83-84).

\section{MIEJSCE KREATYWNOŚCI W TEORII EDUKACJI KULTURALNEJ}

Najbardziej ogólny sposób rozumienia edukacji kulturalnej wskazuje na jej dwoisty charakter, wobec czego definiuje się ją jako edukację do kultury oraz edukację przez kulturę. Zakłada się tym samym, że kultura z jednej strony stanowi cel 
edukacji, z drugiej zaś strony - jest istotnym środkiem edukacji, czynnikiem rozwoju społecznego i osobowościowego.

Spośród licznych definicji edukacji kulturalnej sformułowanych na gruncie teorii pedagogicznej kategoria kreatywności uwypuklona została właściwie jedynie w ujęciu zaproponowanym przez Urszulę Kaczmarek, według której edukację kulturalną określić można jako proces humanizacji człowieka, na który składają się działania podejmowane w celu kształtowania wrażliwości na wartości, bogacenia aktywności, wyobraźni i kreatywności oraz rozwijania akceptacji na rozmaite zjawiska artystyczne i społeczne (Grad, Kaczmarek 2005, s. 140).

Przyglądając się bardziej szczegółowo głównym założeniom formułowanym w ramach konkretnych koncepcji i wizji edukacji kulturalnej, zauważyć można, iż kreatywność stanowi jedną z kluczowych kategorii wychowania estetycznego. Szczególnie silnie uwidacznia się w nurcie wychowania przez sztukę. Klasyczne ujęcia edukacji estetycznej w szerszym sensie podkreślają, iż wychowanie przez sztukę dotyczy kształcenia całej osobowości człowieka. Poprzez rozwijanie wrażliwości estetycznej jednostki dokonuje się rozwój sfery intelektualnej, społeczno-moralnej, a także pobudzenie wyobraźni oraz dyspozycji twórczych. Odbiór sztuki oraz własna aktywność artystyczna przyczyniają się do kreatywnej percepcji świata oraz twórczego nań oddziaływania - nie tylko w sferze artystycznej, ale we wszystkich obszarach działalności ludzkiej.

Pośrednio kategoria kreatywności pojawia się również w ujęciu edukacji kulturalnej rozumianej jako sublimowanie aktywności kulturalnej, jeśli przyjąć definicję uczestnictwa w kulturze zaproponowaną przez Andrzeja Tyszkę, zgodnie z którą oznacza ono „indywidualny udział w zjawiskach kultury - przyswajanie jej treści, używanie jej dóbr, podleganie obowiązującym w niej normom i wzorcom, ale też tworzenie nowych jej wartości oraz odtwarzanie i przekształcanie istniejących" (Tyszka 1971, s. 54). Edukacja kulturalna jest wówczas rozumiana jako intencjonalne, długofalowe oraz zróżnicowane czynności, których celem jest rozwijanie aktywności kulturalnej. Zadania edukacji kulturalnej skoncentrowane są w tym przypadku głównie wokół inicjowania i rozwijania postawy twórczej wobec dóbr kultury, upowszechniania aktywnego udziału w ambitnych formach życia kulturalnego, jak również wyposażania w kompetencje kulturalne (Jankowski 1996, s. 44).

Pomijając wskazane ujęcia eksponujące w bardziej lub mniej bezpośredni sposób kreatywność jako ważny element i cel edukacji kulturalnej, stwierdzić należy, iż mimo ewidentnych związków i zależności łączących omawiane tu kategorie, kreatywność w perspektywie edukacji kulturalnej stanowi raczej temat utajony, funkcjonujący w cieniu takich obszarów kluczowych jak aktywność kulturalna czy kompetencja kulturalna. Można by nawet postawić zarzut, iż jest w pewnym stopniu kategorią zaniedbaną, eksponowaną w zasadzie przede wszystkim 
w kontekście animacji społeczno-kulturalnej, ujmowanej przez część badaczy jako metoda edukacji kulturalnej. Połączenie to uwypukla w sposób zasadniczy kategorie twórczości i kreatywności. W literaturze przedmiotu podkreśla się bowiem, iż animacja jako metoda edukacji kulturalnej pobudza kreatywność, inicjując procesy poszukiwania rozmaitych rozwiązań, co nabiera szczególnego znaczenia w warunkach dynamicznych przemian społecznych. W takim rozumieniu animacja stanowi metodę wspierającą wychowanie kreacyjne (Schindler 2000, s. 13). Idee twórczości i kreatywności pojawiają się między innymi w sferze celów, zasad oraz wartości leżących u podstaw animacji społeczno-kulturalnej. W literaturze zagranicznej spotkać się możemy nawet z odrębnym nurtem animacji określanej mianem „animacji kreatywno-ekspresyjnej”, który polega na wspieraniu jednostek i grup społecznych w wyrażaniu siebie poprzez rozmaite działania artystyczne. Działający w ramach charakteryzowanego nurtu animatorzy określani są mianem praktykujących artystów, których celem jest stwarzanie okazji do opracowywania, projektowania, tworzenia bądź współtworzenia wytworów artystycznych (Smith 2009). Kreatywność jest również jednym z kluczowych pojęć w obszarze nurtu „community arts”. Dla praktyków tego nurtu charakterystyczne jest wręcz odchodzenie od pojęcia sztuki na rzecz idei kreatywności, co związane jest $\mathrm{z}$ wizją kultury otwartej, dostępnej dla wszystkich członków społeczności, bez względu na uwarunkowania psychologiczne, społeczne czy ekonomiczne. Jeden z praktyków community arts - Nick Clements, w następujący sposób wyjaśnia to zjawisko: „kreatywność musi być dostępna dla wszystkich oraz ekspansywna. Kreatywność to siła, którą każdy z nas dysponuje, potrafi zrozumieć i do której potrafi dotrzeć" (Clements 2004, s. 39). Animacyjny sposób myślenia na temat kreatywności koresponduje z głoszoną przez J. Kozieleckiego wizją „człowieka transgresyjnego”, dążącego do ustawicznego przekraczania własnych granic, warunkującego rozwój osobowości i tożsamości człowieka.

\section{KREATYWNOŚĆ JAKO FUNDAMENT EDUKACJI KULTURALNEJ W SZKOLE}

Przywołane we wstępie do niniejszych rozważań dokumenty strategiczne, w których wyeksponowana została kategoria kreatywności, zaznaczają istotną rolę procesów edukacyjno-kulturowych w rozwijaniu postawy kreatywnej. W Konkluzjach Rady Unii Europejskiej z dnia 27 listopada 2009 r. w sprawie promowania pokolenia kreatywnego: rozwijanie kreatywności i innowacyjności dzieci i młodzieży dzięki ekspresji kulturowej i dostępowi do kultury podkreślono, że: 
- „dostęp do rozmaitych form ekspresji kulturowej, działań artystycznych i dzieł sztuki oraz kontakt z nimi zapewniane od najmłodszych lat są ważne dla rozwoju osobistego, budowy tożsamości, wysokiej samooceny i indywidualnego poczucia przynależności; dzięki niemu dzieci i młodzież nabywają kompetencji międzykulturowych oraz innych umiejętności, które mają znaczenie dla włączania społecznego i które pomagają im stać się aktywnymi obywatelami i zyskać szanse na zatrudnienie w przyszłości;

- uczestnictwo w działaniach kulturalnych, w tym bezpośredni kontakt z artystami, może zwiększyć kreatywność i innowacyjność wszystkich dzieci i młodych ludzi dzięki stymulowaniu kreatywnego myślenia, wyobraźni i autoekspresji;

- promowanie kultury i ekspresji kulturowej w szkołach i innych placówkach edukacyjnych oraz w kontekście uczenia się pozaformalnego [...] przyczynia się do pełnego rozwoju jednostki, podnoszenia motywacji i poziomu wyników w nauce, a także do zwiększania kreatywności i innowacyjności” (Jagodzińska 2013, s. 329).

Podobne zapisy odnaleźć można w dokumentach rodzimych. Opracowana przez Ministerstwo Kultury i Dziedzictwa Narodowego Strategia Rozwoju Kapitału Społecznego na lata 2011-2020 zakłada wizję społeczeństwa, w którym „różnorodność talentów, umiejętności, kompetencji i punktów widzenia znajduje wspólną przestrzeń aktywności, służąc tworzeniu innowacji w sferze społecznej, gospodarczej i kulturowej, a systemy edukacji powszechnej, w tym ustawicznej, działają na rzecz kształtowania postaw i kompetencji społecznych" (Strategia Rozwoju..., 2011, s. 18).

Szczególną rolę w prezentowanej tu wizji pełnić ma szkoła, która ma się przyczynić do realnego rozwijania postaw oraz kompetencji społecznych, rozumianych głównie jako kreatywność, kooperatywność i komunikatywność. Jednocześnie różnorodne analizy teoretyczno-badawcze pokazują, iż to właśnie szkoła jawi się jako jedna z podstawowych barier w procesie twórczym. Mówi się więc o szkole jako instytucji utrwalającej istniejący ład społeczny, przystosowującej się przede wszystkim do zewnętrznych wskaźników efektywności, jak również kryteriów ewaluacji. Zbigniew Kwieciński określa ten typ szkoły mianem „szkoły zorientowanej na przejście przez programy i lata szkolne oraz na realizację programów nauczania" (Kwieciński 2008, s. 123). Podobny typ szkoły Bogdan Idzikowski określa mianem „szkoły zachowawczej”, stawiając go niejako w opozycji wobec „szkoły krytyczno-kreatywnej”, charakteryzującej się między innymi pluralizmem aksjologicznym i organizacyjnym, ideą łączenia tradycji z nowoczesnością, dialogiem międzypokoleniowym oraz misją wychowania jednostki zaradnej, zdolnej do samodzielności i funkcjonowania w warunkach konkurencyjności (Idzikowski 2000, s. 261). 
Wśród najważniejszych zastrzeżeń, jakie formułowane są wobec szkoły w kontekście twórczości i kreatywności, wskazać można: kształtowanie postawy konformistycznej oraz zachowawczego sposobu myślenia, rozwijanie encyklopedycznej wiedzy kosztem procesów myślowych uczniów, hamowanie ich zainteresowań, a co za tym idzie - również predyspozycji i możliwości twórczych, przedmiotowe traktowanie ucznia (w kategoriach obiektu przyswajania wiadomości) (Szmidt 2005, s. 86).

Przytoczone zarzuty stanowią kolejny argument uzasadniający konieczność uwypuklenia aspektów związanych z kreatywnością w myśleniu o edukacji kulturalnej. Jak już wspomniano, w niewielkim stopniu jest ona artykułowana na gruncie teorii naukowej, rzadko również pojawia się także w wizjach praktyków i realizatorów działań edukacyjno-kulturalnych. Ze świeżego, bo ubiegłorocznego raportu z badań diagnostycznych Edukacja kulturalna w województwie lubelskim $z$ perspektywy praktyków wynika, iż w grupie głównych celów edukacji kulturalnej wskazywanych przez badanych nauczycieli, animatorów oraz pracowników instytucji kultury i organizacji pozarządowych wskazuje się najczęściej takie zadania, jak: kształtowanie nawyków i potrzeb uczestnictwa w kulturze, poszerzenie horyzontów, umożliwienie nabycia wiedzy poprzez osobiste doświadczenia, przygotowanie do odbioru dzieł sztuki, rozwijanie kompetencji społecznych i interpersonalnych, kształtowanie postawy otwartości i szacunku wobec różnorodności, wzmacnianie poczucia tożsamości lokalnej, zapewnienie wartościowych form spędzania czasu wolnego (Edukacja kulturalna...2017, s. 24-32).

Podobnie jak w przypadku ujęć teoretycznych, również w wypowiedziach praktyków działających w obszarze edukacji kulturalnej, mamy więc do czynienia z utajeniem oraz enigmatycznością kategorii kreatywności. Tu również pojawia się ona bowiem niejako w cieniu innych celów i funkcji edukacji kulturalnej. Tymczasem sami uczestnicy procesów edukacji kulturalnej dopominają się o przyznanie kreatywności większej rangi w konkretnych działaniach edukacyjnych. W 2013 roku w Lublinie w ramach Tygodnia Edukacji Pozaformalnej i Kulturalnej organizowanego przez Fundację „Teatrikon” odbyła się konferencja „O edukacji i kulturze”, podczas której podjęto dyskusję na temat nowych systemów edukacji, metod nauczania oraz aktywności kulturalnej młodzieży. Głos w dysusji zabrała również młodzież. Oto jedna $\mathrm{z}$ wypowiedzi młodego pokolenia: „W zasadzie w liceum spędzamy około pięćdziesiąt procent całego swojego czasu przez okres trzech lat. Uczymy się tego, co mamy zdać na maturze, podczas gdy jest masa umiejętności, $\mathrm{z}$ których normalny człowiek $\mathrm{w}$ normalnym życiu powinien umieć korzystać. Kończymy liceum bez nich, a co gorsza, bez przekonania, że są one potrzebne. Należą do nich kreatywność i poczucie indywidualności, chęć zmieniania swojej rzeczywistości i świadomość, że da się to zrobić. Musimy uczyć się czegoś innego, a nie tylko bycia uczniem [...]" (Szkołę trzeba wymyślić od nowa...2013, s. 23). 
Owo zadanie bycia nie tylko uczniem, ale również człowiekiem - indywidualnym, kreatywnym, potrafiącym tworzyć i zmieniać rzeczywistość - dokonywać się winno oczywiście w wielu rozmaitych sferach życia, jednak to obszar edukacji kulturalnej zdaje się być tutaj przestrzenią kluczową. Zadanie budzenia i rozwijania postawy kreatywnej realizować można w ramach różnorodnych działań proponowanych przez szkołę. Szczególny potencjał w tym zakresie mają jednak wszelkie formy związane z edukacją pozaformalną oraz pozalekcyjną, charakteryzujące się większą niż ma to miejsce w przypadku zajęć obligatoryjnych otwartością na innowacje i inicjatywy. Wśród fundamentalnych cech edukacji pozalekcyjnej wskazuje się pomysłowość, alternatywność, wyobraźnię i kreatywność (Ciczkowski 1999, s. 355). Cechy te będą jeszcze silniej widoczne, jeśli przestrzeń zajęć pozalekcyjnych wypełnimy autentycznymi założeniami edukacji kulturalnej. Autentycznymi, bo wiele $\mathrm{z}$ proponowanych w szkołach form określić można mianem pozornych. Nadal nierzadko bowiem mamy do czynienia z działaniami, o których już ponad dwadzieścia lat temu pisała Krystyna Ferenz: „patrząc na wielce uporządkowane procesy lekcyjne i sformalizowane zajęcia pozalekcyjne, wydaje się, że w tych wszystkich zajęciach dla dzieci, które mają stymulować ich rozwój, wyzwalać to, co w nich inne, wartościowe, brakuje miejsca dla indywidualnych zachcianek, swoistych „fanaberii”, trochę dziecinnych, trochę ekscentrycznych, wyrażających ich właściwe sobie odczuwanie, tworzenie” (Ferenz 1996, s. 127).

W związku z powyższym, kreatywność jako przedmiot i cel szkolnej edukacji kulturalnej zaistnieć może najpełniej w działaniach o charakterze animacyjnym. Próbę określenia roli animacji społeczno-kulturalnej w szkolnych praktykach edukacyjnych podjęła Barbara Jedlewska. Zdaniem autorki, animacja jawi się jako wartościowa metoda działań, którą wykorzystywać można na różnych poziomach edukacji. Etap edukacji przedszkolnej to czas kształtowania się nawyku kontaktów dzieci z kulturą i wartościami. Szczególnego znaczenia w tym czasie nabierają działania o charakterze inspirującym, motywacyjnym, stymulującym i wspierającym procesy szeroko rozumianej kreacji oraz autoedukacji, stanowiące podstawę rozwoju takich kompetencji i cech, jak: refleksja, odpowiedzialność, radość tworzenia, samodzielność, świadomość wspólnoty, tolerancja, zdolność interakcji, empatia, zaangażowanie, wytrwałość, spontaniczność, innowacyjność. W przypadku edukacji szkolnej rola działań animacyjnych polega natomiast przede wszystkim na odkrywaniu potencjałów i zainteresowań młodego pokolenia, jak również rozbudzaniu potrzeby kontaktu ze sztuką. B. Jedlewska zaznacza przy tym, iż istotą działań animacyjnych w szkole nie jest wyłącznie przekaz kultury. Główny ich sens polega na uczeniu interpretowania i rozumienia zjawisk związanych z kulturą, pobudzaniu twórczej aktywności, a co za tym idzie - wrażliwości, kreatywności i wyobraźni (Jedlewska 2003, s. 38). 


\section{PODSUMOWANIE}

Pojawiająca się w ostatnich latach moda na kreatywność prawdopobnie obowiązywać będzie nadal, przynajmniej przez kilka sezonów. Ważne, aby szły za nią konkretne treści i działania, szczególnie w przypadku dyscyplin społecznych i humanisycznych, które w sposób bezpośredni oddziaływują na człowieka. I chociaż tak w teorii, jak i w praktyce edukacji kulturalnej kreatywność nierzadko stanowi kategorię utajoną, z całą pewnością uznać ją należy za przedmiot i cel działań o charakterze edukacyjno-kulturalnym. Przypomina o tym współczesna jej wykładnia w postaci animacji społeczno-kulturalnej - rozumianej jako skuteczna metoda inicjowania działań twórczych, wyzwalania kreatywności, pobudzania potencjałów i zainteresowań, aktywizowania jednostek, grup i społeczności lokalnych. Animacja jako metoda edukacji kulturalnej oraz edukacji kreatywnej w szkole znajduje swoje zastosowanie zarówno w przestrzeni zajęć obligatoryjnych (gdzie może być odpowiedzią na powszechne zjawisko nudy szkolnej), jak też w sferze edukacji pozalekcyjnej (głównie w kontekście organizacyjno-metodycznym). Jest również istotnym narzędziem wzmacniania szkolnej wspólnoty, tworzenia przyjemnej atmosfery oraz budowania pozytywnego otoczenia szkoły.

\section{LITERATURA}

Ciczkowski W., 1999, Zajęcia pozalekcyjne i pozaszkolne, W: D. Lalak, T. Pilch (red.), Elementarne pojecia pedagogiki społecznej i pracy socjalnej. Warszawa, Wydawnictwo Akademickie „Żak”.

Clements N., 2004, Creative Collaboration. Swansea, Sound of the Heart Publishers. Edukacja kulturalna w województwie lubelskim z perspektywy praktyków. Raport $z$ badania diagnostycznego, 2017. Lublin, Centrum Spotkania Kultur.

Ferenz K., 1996. Nie wykorzystane możliwości edukacji kulturalnej dzieci. W: D. Jankowski (red.), Edukacja kulturalna i aktywność artystyczna. Poznań, Wydawnictwo Naukowe Uniwersytetu Adama Mickiewicza.

Grad J., Kaczmarek U., 2005, Organizacja i upowszechnianie kultury w Polsce. Zmiany modelu. Poznań, Wydawnictwo Naukowe Uniwersytetu Adama Mickiewicza.

Idzikowski B., 2000, Edukacja kulturalna - między szkołą a instytucjami kultury. W: B. Idzikowski, E. Narkiewicz-Niedbalec (red.), Edukacja kulturalna dzieci i młodzieży. Zielona Góra, Regionalne Centrum Animacji Kultury; Warszawa, Centrum Animacji Kultury. Jagodzińska K., 2013, Edukacja kulturalna na rzecz kreatywności i innowacyjności. W: J. Hausner, A. Karwińska, J. Purchla (red.), Kultura a rozwój. Warszawa, Narodowe Centrum Kultury, 327-343. 
Jankowski D., 1996, Wartości - aktywność artystyczna - paradygmaty działalności kulturalnej. W: D. Jankowski (red.), Edukacja kulturalna i aktywność artystyczna. Poznań, Wydawnictwo Naukowe Uniwersytetu Adama Mickiewicza.

Jedlewska B., 2003, Animacja jako metoda edukacji kulturalnej w społecznościach lokalnych. W: J. Żebrowski (red.), Animacja kulturalna i społeczno-wychowawcza $w$ środowiskach lokalnych. Gdańsk, Gdańskie Towarzystwo Naukowe, Gdańska Wyższa Szkoła Humanistyczna.

Kwieciński Z., 2008, Tożsamość szkoły a zmiana i rozwój. W: R. Wawrzyniak-Beszterda (red.), Życie szkołą. Prace dedykowane Profesor Marii Dudzikowej. Poznań, Oficyna Wydawnicza Garmond.

Parys K., 2013, Przestrzeń dla kreatywności uczniów z niepełnosprawnościa intelektualna w stopniu lekkim. Kraków, Oficyna Wydawnicza Impuls.

Schindler A., 2000, O istocie animacji. W: K. Hrycyk (red.), Animacja społecznokulturalna wobec przemian cywilizacyjnych. Animacja - animator i jego kształcenie. Czterdziestolecie Państwowego Studium Kształcenia Animatorów Kultury i Bibliotekarzy we Wrocławiu. Wrocław, Państwowe Pomaturalne Studium Kształcenia Animatorów Kultury i Bibliotekarzy.

Smith M.K., 2009, Animateurs, animation and fostering learning and change. The encyclopaedia of informal education, źródło: www.infed.org/mobi/animateursanimation-learning-and-change, [dostęp: 10.08.2018].

Strategia Rozwoju Kapitału Społecznego 2011-2020, 2011. Warszawa, Ministerstwo Kultury i Dziedzictwa Narodowego.

Szkołe trzeba wymyślić od nowa (debata), 2013, W: Kultura edukacji/ edukacja kultury. Materiały pokonferencyjne. Tydzień Edukacji Pozaformalnej i Kulturalnej, Lublin, Fundacja Twórczości, Edukacji i Animacji Młodzieży „Teatrikon”.

Szmidt K.J., 2005, Pedagogika twórczości. Idee - aplikacje - rady na twórczą drogę. Kraków, Oficyna Wydawnicza Impuls.

Szmidt K.J., 2013, Trening kreatywności. Podręcznik dla pedagogów, psychologów i trenerów grupowych. Gliwice, Wydawnictwo HELION.

Tyszka A., 1971, Uczestnictwo w kulturze. O różnorodności stylów życia. Warszawa, Państwowe Wydawnictwa Naukowe.

\section{DOKUMENTY}

Europe 2020. A European strategy for smart, sustainable and inclusive growth, Brussel 2010.

Konkluzje Rady z dnia 27 listopada 2009 r. w sprawie promowania pokolenia kreatywnego: rozwijanie kreatywności i innowacyjności dzieci i młodzieży dzięki ekspresji 
kulturowej i dostępowi do kultury. W: Dziennik Urzędowy Unii Europejskiej C 301 z 11.12.2009.

Lisbon Strategy. Commission of the European Communities, Brussel 2000.

\title{
CREATIVITY AS A SUBJECT AND GOAL OF CULTURAL EDUCATION
}

\begin{abstract}
The purpose of the article is to draw attention to the importance of the creativity aspect in the theory and practice of cultural education. The considerations contained in this text focus on the actual and postulated place of creativity in the concepts of cultural education, its role in school practice and educational goals which characterize the so-called creative school. The article brings up the most important concepts of cultural education: aspects of creativity and creative output as well as strategic documents in which the connections between creativity, culture and education were articulated. The article pointed out the main areas of school cultural education, justifying the need of strengthen and emphasize the idea of creativity in the perspective of education and culture.
\end{abstract}

Keywords: Creativity, cultural education, creative school 